\title{
PENGARUH PERSEPSI SISWA MADRASAH ALIYAH TENTANG PENGHAPUSAN MATERI JIHAD PADA MATA PELAJARAN FIQH TERHADAP PEMAHAMAN SISWA TENTANG JIHAD
}

\author{
Muhammad Syihabuddin \\ Universitas Ibn Khaldun Bogor
}

\begin{abstract}
By removing and revising and replacing Islamic teachings on Jihad and the Caliphate, it will alienate generations of people and they will become phobic towards the teachings of their own religion. Moreover, leading to the opinion that Jihad and the caliphate are no longer relevant to the current context. Even though the khilafah is the solution to solve the problems of life today. So it is very wrong if Islamic teachings should be revised or moderate its teachings. This massive, structured moderation step is absolutely useless. In fact, it will bring this ummah to be increasingly radicalized secular mind. Increasingly want to get away from Islamic law. Because it should be stopped or Allah SWT will remind you in His way. The purpose of this study was to determine the effect of students 'perceptions of Madrasah Aliyah about the elimination of Jihad material on the subject of fiqh on students' understanding of jihad. The method suitable for use in this research is descriptive method with a quantitative approach. The research sample consisted of 172 respondents. Data analysis using inferential. The simple correlation technique used is Product Moment. Based on the data analysis, it was concluded that there was an influence on students 'perceptions of Madrasah Aliyah about the elimination of Jihad material in the subject of fiqh on students' understanding of jihad. This is indicated by the results of the correlation significance test showing that $t>t$ table (13.68> 1.974). Thus the research hypothesis which states that there is an influence on the perceptions of Madrasah Aliyah students about the elimination of Jihad material on the subject of fiqh on students' understanding of jihad has been tested.
\end{abstract}

Keywords: Student Perception, Jihad Material, Fiqh Lessons

\section{PENDAHULUAN}

Dalam pelaksanaan mata pelajaran Fiqih, Guru Fiqih diharapkan memiliki pengetahuan dan wawasan yang luas tentang suatu strategi pembelajaran yang bervariasi. Namun kenyataannya yang terjadi sekarang, banyak beberapa guru yang ada pada madrasah dibebankan dengan peraturan/kebijakan dari kementrian agama dalam mengimplementasikan pembelajarannya khususnya pada mata pelajaran Fiqh, guru diharapkan mempunyai alternatif strategi pembelajaran lain jika kebijakan kementerian agama direalisasikan disetiap madrasah dan kondisi seperti ini tidak membuat siswa terganggu pada materi yang direvisi semestinya diajarkan karena dikhawatirkan hal ini berdampak pada hasil belajar yang ada pada diri siswa. Sehingga persepsi siswa terhadap kebijakan dari kementerian agama sangat dibutuhkan untuk menjaga kualitas pembelajaran di madrasah. 
Adapun revisi tentang materi Jihad sesuai ketentuan regulasi penilaian yang diatur pada Surat Keputusan Dirjen Pendidikan Islam Nomor 3751, Nomor 5162, dan Nomor 5161 Tahun 2018 tentang Juknis Penilaian Hasil Belajar pada MA, MTs, dan MI. Kementerian Agama (Kemenag) menginginkan materi ujian di madrasah lebih mengedepankan kedamaian, keutuhan, dan toleransi. Selanjutnya, materi Jihad yang tercantum dalam KMA 165 Tahun 2014 itu dinyatakan tidak berlaku dan telah diperbaiki dalam KMA 183 Tahun 2019. Kementerian Agama melalui surat edaran tertanggal 4 Desember 2019 memerintahkan Kepala Bidang Pendidikan Madrasah/Pendidikan Islam mengimplementasikan KMA Nomor 183 Tahun 2019. Salah satunya, seluruh materi ujian di madrasah yang mengandung konten perang atau Jihad telah diperintahkan untuk ditarik dan diganti. Revisi materi Jihad justru akan memberikan pengaruh pada siswa madrasah dan juga akan melemahkan semangat juang mereka dalam meraih prestasi belajar. Karena selama ini materi Jihad mengajarkan, kita untuk mencapai prestasi, Jihad melawan kemalasan, Jihad melawan hawa nafsu. Jadi tidak diajarkan Jihad dalam artian perang mengangkat senjata, kecuali dalam situasi-situasi tertentu. Namun itupun, harus dapat izin dari penguasa dengan syarat-tertentu pula.

Agar pengajaran mata pelajaran Fiqh kondusif. Sehingga dapat meningkatkan keberhasilan kegiatan belajar mengajar di kelas, terutama pemahaman siswa tentang jihad, walaupun kebijakan perubahan materi tentang Jihad di Madrasah Aliyah dipindakhan, maka penulis akan mencari tahu lebih dalam melalui penelitian.

\section{METODOLOGI PENELITIAN}

Setiap penelitian memerlukan metode agar proses penelitian dapat berjalan lancar dan mencapai tujuan yang telah ditetapkan. Sesuai dengan permasalahan yang diteliti, yaitu mengenai kejadian-kejadian dan peristiwa yang sedang berlangsung maka metode yang sesuai untuk digunakan dalam penelitian ini adalah metode deskriptif dengan pendekatan kuantitatif.

\section{KAJIAN TEORI}

\section{A. Tinjauan tentang Persepsi Siswa}

Persepsi merupakan suatu proses dimana seseorang mengorganisasikan dalam pikirannya, menafsirkannya, mengalami, dan mengelola pertanda atas segala sesuatu yang terjadi di lingkungannya. Sedangkan menurut Abizar (1998), mengatakan bahwa persepsi adalah suatu proses dengan mana seseorang individu memilih, mengevaluasi dan mengorganisasi stimulus dari lingkungannya. Persepsi juga menentukan cara kita berperilaku terhadap suatu obyek atau permasalahan, bagaimana segala sesuatu itu mempengaruhi persepsi seseorang nantinya akan mempengaruhi perilaku yang dipilihnya. 
Persepsi menurut Jalaludin (2013), adalah pengalaman tentang objek, peristiwa, atau hubungan-hubungan yang diperoleh dengan menyimpulkan informasi dan menafsirkan pesan.

Persepsi adalah suatu proses tentang petunjuk-petunjuk inderawi (sensory) dan pengalaman masa lampau yang relevan diorganisasikan untuk memberikan kepada kita gambaran yang terstruktur dan bermakna pada suatu situasi tertentu. (Walgito, 2013).Senada dengan hal tersebut Atkinson dan Hilgard (2007) mengemukakan bahwa persepsi adalah proses dimana kita menafsirkan dan mengorganisasikan pola stimulus dalam lingkungan. Gibson dan Donely (2011), menjelaskan bahwa persepsi adalah proses pemberian arti terhadap lingkungan oleh seorang individu.

Sedangkan Persepsi sosial dapat diartikan sebagai proses perolehan, penafsiran, pemilihan, dan pengaturan informasi indrawi tentang orang lain.

Apa yang diperoleh, ditafsirkan, dipilih, dan diatur adalah informasi indrawi dari lingkungan sosial, serta yang menjadi fokusnya adalah orang lain.

\section{B. Tinjauan Pemahaman Siswa}

Pemahaman adalah kesanggupan untuk mendefenisikan, merumuskan kata yang sulit dengan perkataan sendiri. Dapat pula merupakan kesanggupan untuk menafsirkan suatu teori atau melihat konsekwensi atau implikasi, meramalkan kemungkinan atau akibat sasuatu (Nasution, 2017:27).

Menurut Benyamin S. Bloom pemahaman adalah kemampuan seseorang untuk mengerti atau memahami sesuatu setelah sesuatu itu diketahui dan di ingat. Seorang peserta didik dikatakan memahami sesuatu apabila ia dapat memberikan penjelasan atau memberi uraian yang lebih rinci tentang hal itu dengan menggunakan bahasa sendiri (Sudijono, 2011:50)

Ngalim Purwanto mengemukakan bahwa pemahaman atau komprehensi adalah tingkat kemampuan yang mengharapkan testee mampu memahami arti atau konsep, situasi, serta fakto yang diketahuinya. Dalam hal ini testee tidak hanya hafal cara verbalistis, tetapi memahami konsep dari masalah atau fakta yang ditanyakan (Purwanto, 2010:44).

Menurut Sardiman (2011:78), pemahaman dapat diartikan menguasai sesuatu dengan fikiran. Menurut Winkel (2009:218), pemahaman mencakup kemampuan untuk menangkap makna dan arti dari bahan yang dipelajari.

Berdasarkan teori di atas dapat disintesiskan bahwa pemahaman siswa adalah kemampuan dalam memaknai hal-hal yang terkandung dalam suatu teori maupun konsep-konsep yang dipelajari.

\section{Tinjauan tentang Jihad}

Jihad dalam Islam mempunyai kedudukan yang sangat tinggi. Dikarenakan keutamaan Jihad banyak sekali tertera dalam Al-Qur'an dan Al-sunnah. Rasullah SAW menganggapnya sebagai puncak amalan. 
Kemuliaan hal itu juga bisa dilihat dari menyatunya sebagai macam bentuk ibadah didalam Jihad. Memadukan ibadah lahiriyah maupun ibadah batiniyah. Dari aspek ibadah lahiriyah bisa ditilik pada pengorbanan tenaga, harta, pikiran dan jiwa. Sedangka dari aspek ibadah batiniyah didalamnya mencakup zuhud di dunia, meninggalkan tanah air dan tempat tinggalnya, dan meninggalkan kesenangan duniawi.

Kata Jihad memiliki dua definisi atau dua pengertian: secara etimologi dan terminologi, secara etimologi, Jihad artinya berjuang atau perjuangan yang dilakukan dengan sungguh-sungguh (Burhanudin, 2015:35). Atau dengan kata lain, Jihad adalah pengerahan maupun perbuatan, dalam peperangan. Kata Jahd atau Juhd artinya kekuatan, kekuasaan, atau kesanggupan. Ia juga bisa berarti Masyaqah (kesukaran atau kesulitan). Kata Jahd sama dengan kata Thaqah dan Wus (kekuatan dan kesanggupan). Kata Jahada--Yajhadu---Jahdan, dan kata Ijtahada, maknanya sama dengan kata Jada (bersungguhsungguh) (Ramadhun, 2014:11). Dan jika kata Jihad dikaitkan denga kata Fii Sabilillah, maka masuklah definisi terminologi. Menurut definisi terminology, Jihad adalah memerangi kaum kafirin yang memerangi Islam dan umat Islam dalam rangka menengakkan kalimat Allah (Ramadhun, 2014:12).

Istilah Jihad berasal kata Jahadah (kata benda abtrak, Juhud), yang bermakna "berusaha". Secara yuridis-teologis berarti berusaha sekuat tenaga di jalan Allah,. Untuk menyebarkan keimanan dan firman-firman Allah ke seluruh dunia. Ajaran yang bersifat individual ini merupakan suatu upaya pencapaian keselamatan, sebab Jihad merupakan tuntunan Allah yang dapat mengantarkan manusia langsung menuju surga. (Khaduri, 2014:41).

Kata jihad berasal dari kata jahada yujahidu jihadan wa mujihadatan. Asal katanya adalah jahada yajhadu jahdan/juhdan yang berarti kekuatan (al-thalaq) dan upaya jerih payah (al-masyaqqah). Secara bahasa jihad berarti mengerahkan segala kekuatan dan kemampuan untuk membela diri dan mengalahkan musuh. (Indonesia, 2016). Jihad bermakna usaha memberdayakan serta mengerahkan kekuatan dan kemampuan untuk mewujudkan satu tujuan. (Yazdi, 2016).

Jihad adalah sebuah term yang memiliki dua pengertian, yaitu pengertian khusus dan pengertian umum. Yang dimaksud jihad dengan pengertian khusus adalah sebagaimana terminologi jihad menurut para ulama fikih yaitu memerangi orang kafir dalam rangka menjaga dan mempertahankan agama serta meninggikan kalimat Allah di muka bumi.

Adapun pijakan jihad dalam pengertian umum adalah dikembalikan kepada definisi jihad secara etimologis yaitu mencurahkan segenap usaha dan kemampuan dalam rangka meraih kebaikan dan kemaslahatan. Hal ini selaras dengan pernyataan Abul A'la al Maududi: "Jihad merupakan kalimat universal yang mencakup seluruh bentuk upaya dan pengorbanan.” (Furaih, 2010:45). Atau mengacu kepada terminologi jihad menurut pernyataan Ibn Taimiyah (w. $728 \mathrm{H}$ ) yang memberikan salah satu definisi jihad dengan pengertian yang umum dan lebih luas: Jihad adalah mencurahkan segenap upaya. Yaitu 
kemampuan dalam meraih yang dicintai Al Haq (Allah) dan mencegah hal-hal yang Dia benci. Dengan kata lain esensi jihad adalah bersungguh-sungguh mendapatkan apa yang dicintai Allah berupa keimanan dan amal shaleh serta mencegah segala yang dimurkai Allah baik berupa kekufuran, kefasikan dan kemaksiatan.

\section{Tinjauan tentang Fiqih}

Kata fiqih secara bahasa berasal dari faqaha yang berarti "memahami" dan "mengerti". Sedangkan menurut istilah syar'i ilmu fiqih ialah" ilmu yang berbicara tentang hukum-hukum syar' $i$ amali (praktis) yang penetapannya diupayakan melalui pemahaman yang mendalam terhadap dalia-dalilnya yang terperinci dalam nash (Alqur'an dan hadits) (Koto, 2014:21)

Hukum syar' $i$ yang dimaksud dalam definisi diatas adalah segala perbuatan yang diberi hukumnya itu sendiri dan diambil dari syariat yang dibawa oleh Nabi Muhammad SAW. Adapun yang dimaksud kata amali diatas adalah perbuatan Amalia orang mukallaf dan tidak termasuk keyakinan dari mukallaf itu. Sedangkan dalia-dalil terperinci maksudnya adalah dalia-dalil yang terdapat dan terpapar dalam nash di mana satu per satunya menunjuk pada satu hukum tertentu.

Penggunaan kata syari'ah menjelaskan bahwa, fiqih itu menyangkut ketentuan yang bersifat syar'i yaitu sesuatu yang berasal dari kehendak Allah. Kata sekaligus menjelaskan bahwa, sesuatu yang bersifat aqli seperti ketentuan bahwa dua kali dua adalah empat atau bersifat hissi seperti ketentuan bahwa api itu panas bukanlah lapangan ilmu fiqih. Kata amaliyah menjelaskan bahwa fiqih itu hanya menyangkut tindak tanduk manusia yang bersifat lahiriah. Dengan demikian hal-hal yang bersifat bukan amaliah seperti masalah keimanan atau akidah tidak termasuk ke dalam lingkungan fiqih. Kata istimbath mengandung arti bahwa fiqih itu adalah hasil penggalian, penemuan, penganalisaan, dan penentuan ketetapan tentang hukum. Jadi fiqih itu adalah hasil penemuan mujtahid dalam hal-hal yang tidak dijelaskan oleh nash. Kata tafsili menjelaskan tentang dalil-dalil yang digunakan seorang faqih atau mujtahid dalam penggalian atau penemuaannya. Dengan demikian secara ringkas dapat dikatakan fiqih itu adalah dugaan kuat yang dicapai seorang mujtahid dalam usahanya menemukan hukum Allah SWT. 


\section{HASIL PENELITIAN DAN PEMBAHASAN}

\section{Pengujian Hipotesis}

Model Summary

\begin{tabular}{|l|r|r|r|r|}
\hline $\begin{array}{l}\text { Mode } \\
1\end{array}$ & \multicolumn{1}{|c|}{$\mathrm{R}$} & $\mathrm{R}$ Square & \multicolumn{1}{|c|}{$\begin{array}{c}\text { Adjusted R } \\
\text { Square }\end{array}$} & $\begin{array}{r}\text { Std. Error of } \\
\text { the Estimate }\end{array}$ \\
\hline 1 & $.724^{\mathrm{a}}$ & .524 & .522 & 4.41736 \\
\hline
\end{tabular}

a. Predictors: (Constant), Pemahaman_tentang_Jihad

ANOVA ${ }^{\mathrm{a}}$

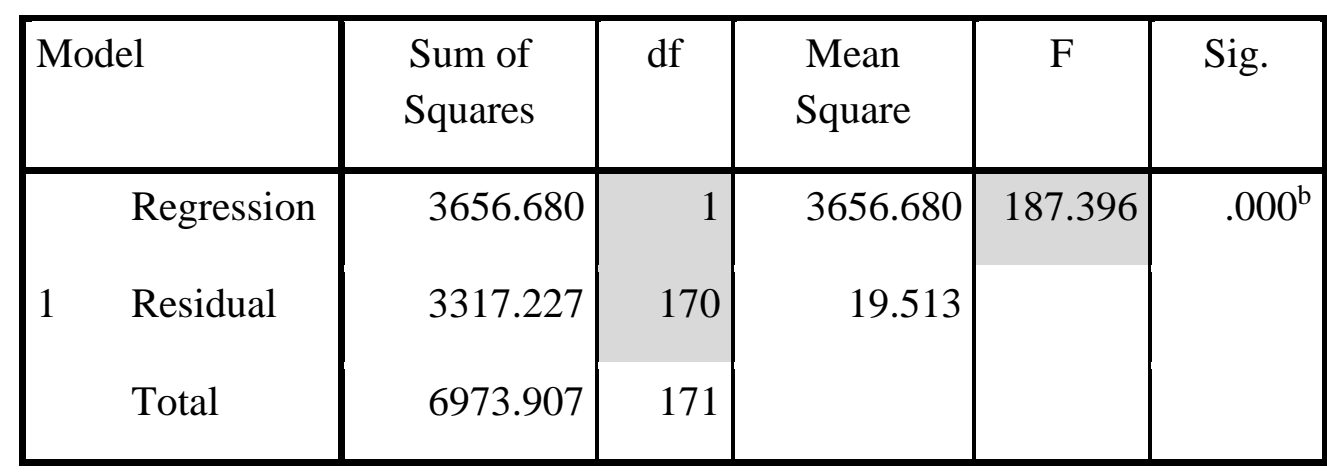

Coefficients $^{\mathrm{a}}$

\begin{tabular}{|l|r|r|r|r|r|}
\hline \multirow{2}{*}{ Model } & \multicolumn{2}{|c|}{$\begin{array}{c}\text { Unstandardized } \\
\text { Coefficients }\end{array}$} & $\begin{array}{l}\text { Standardized } \\
\text { Coefficients }\end{array}$ & $\mathrm{t}$ & Sig. \\
\cline { 2 - 6 } & \multicolumn{1}{|c|}{ B } & Std. Error & Beta & & \\
\hline $\begin{array}{l}\text { (Constant) } \\
\begin{array}{l}\text { Pemahaman_tentang_Ji } \\
\text { had }\end{array}\end{array}$ & 37.950 & 2.295 & & 16.538 & .000 \\
\hline
\end{tabular}

a. Dependent Variable: Penghapusan_Materi_Jihad

Hipotesis yang diajukan dalam penelitian ini adalah : "Terdapat pengaruh persepsi siswa Madrasah Aliyah tentang penghapusan materi Jihad pada mata pelajaran fiqh terhadap pemahaman jihad siswa".

Analisis linier sederhana antara persepsi siswa Madrasah Aliyah tentang penghapusan materi Jihad pada mata pelajaran fiqh terhadap pemahaman jihad siswa 
memiliki persamaan regresi $\hat{Y}=37,95+2,15 X$ dengan arah koefisien regresi sebesar 37,95 dan konstanta sebesar 2,15.

Pengujian mengenai kebenaran hasil regresi tersebut, juga dimaksudkan untuk menguji hipotesis tentang adanya hubungan positif antara persepsi siswa Madrasah Aliyah tentang penghapusan materi Jihad pada mata pelajaran fiqh terhadap pemahaman jihad siswa, maka untuk keperluan itu diperlukan uji signifikasi dan linier terhadap persamaan regresi dengan menggunakan uji F. Berdasarkan hasil uji keberartian

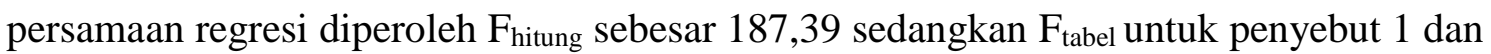
pembilang 170 (1/170) adalah sebesar 3,90, yang berarti nilai $F_{\text {hitung }}>F_{\text {tabel. }}(187,39>$ 3,90). Hal tersebut menunjukkan bahwa hubungan antara variabel persepsi siswa Madrasah Aliyah tentang penghapusan materi Jihad pada mata pelajaran fiqh terhadap pemahaman jihad siswa adalah signifikan.

Hipotesis yang menyatakan bahwa terdapat pengaruh persepsi siswa Madrasah Aliyah tentang penghapusan materi Jihad pada mata pelajaran fiqh terhadap pemahaman jihad siswa, diuji dengan analisis regresi sederhana. Perhitungan analisis regresi sederhana menghasilkan koefisioen korelasi $r_{y}$ sebesar 0,724. Uji keberartian koefisien korelasi dengan uji t. Dari hasil perhitungan diperoleh $t$ hitung sebesar 13,68. Sedangkan $t$ tabel pada taraf kepercayaan $\alpha=0,05$ dengan $\mathrm{dk}=168$ adalah sebesar 1,974. Berdasarkan hasil pengujian signifikansi korelasi menunjukka bahwa $t_{\text {hitung }}>t_{\text {tabel }}(13,68>1,974)$. Dengan demikian hipotesis penelitian yang menyatakan terdapat pengaruh persepsi siswa Madrasah Aliyah tentang penghapusan materi Jihad pada mata pelajaran fiqh terhadap pemahaman jihad siswa teruji kebenarnnya.

\section{Pembahasan Hasil Penelitian}

Berdasarkan hasil analisis uji hipotesis yang telah dilakukan, maka dapat ditemukan fakta bahwa hipotesis yang menyatakan terdapat pengaruh persepsi siswa Madrasah Aliyah tentang penghapusan materi Jihad pada mata pelajaran fiqh terhadap pemahaman jihad siswa teruji kebenarnnya. Hal ini dibuktikan melalui uji t yang menghasilkan $t$ hitung lebih besar dari $t$ tabel.

Temuan penelitian ini juga sejalan dengan penelitian yang dilakukan oleh penelitian dari Ali Imron (2014) menginvestigasi Konsep Jihad dan Implementasinya terhadap pembelajaran di Madrasah pada Studi Kasus di Madrasah Tsanawiyah Nurul Hidayah dan Madrasah al-Khoiriyah Karangawen Demak yang menyimpulkan bahwa Jihad mempunyai banyak makna yang mencakup sejak dari berjuang mengangkat senjata dalam peperangan sampai berjuang melawan hawa nafsu.

Mengenai penghapusan ajaran Jihad, tentu ironis sekali karena hakikatnya adalah menghilangkan ajaran Islam itu sendiri. Ajaran Jihad telah disampaikan oleh Allah swt dengan banyak ayat dalam Al-Qur'an. Seperti dalam QS. Al Baqarah ayat 218, Lafaz “AlJihad' maknanya adalah perang di jalan Allah, sedangkan secara bahasa maknanya 
mengerahkan segala kemampuan. Namun, pengertian secara syar'i Al-Jihad adalah perang. Sehingga Al-Jihad adalah mengerahkan segala kemampuan dalam perang di jalan Allah, baik secara langsung maupun memberikan bantuan berupa harta, pendapat, memperbanyak logistik, atau yang lainnya. (Taqiyuddin An Nabhani, Al Syakhshiyyah al Islamiyyah jilid 2, 147). Imam Ath Thabari pun memaknai jaahaduu dalam ayat ini, dengan berperang dijalan dan agama Allah. Sehingga tidaklah dibenarkan, dengan alasan moderasi jihad hanya diambil makna bahasanya semata. Sehingga amat keliru dan berbahaya apabila ajaran Islam harus direvisi atau menjadikan moderat ajarannya. Langkah ini sama sekali tidak ada manfaatnya, justru akan membawa generasimuda Islam ini semakin berpikir sekuler dan menjauhkan dari kebangkitan Islam.

Disamping itu, sudahlah jelas bahwa Allah swt mencela tindakan mengambil sebagian hukum Allah dan membuang sebagiannya yang lainnya. Balasan bagi tindakan tersebut berupa kehinaan hidup baik di dunia maupun di akhirat.

\section{SIMPULAN}

1. Berdasarkan hasil uji keberartian persamaan regresi diperoleh $F_{\text {hitung }}$ sebesar 187,39 sedangkan $F_{\text {tabel }}$ untuk penyebut 1 dan pembilang 170 (1/170) adalah sebesar 3,90, yang berarti nilai $F_{\text {hitung }}>F_{\text {tabel. }}(187,39>3,90)$. Hal tersebut menunjukkan bahwa hubungan antara variabel persepsi siswa Madrasah Aliyah tentang penghapusan materi Jihad pada mata pelajaran fiqh terhadap pemahaman jihad siswa adalah signifikan.

2. Berdasarkan hasil pengujian signifikansi korelasi menunjukka bahwa $t$ hitung $>t$ tabel $(13,68>1,974)$. Dengan demikian hipotesis penelitian yang menyatakan terdapat pengaruh persepsi siswa Madrasah Aliyah tentang penghapusan materi Jihad pada mata pelajaran fiqh terhadap pemahaman jihad siswa teruji kebenarnnya.

\section{DAFTAR PUSTAKA}

https://www.republika.co.id/berita/q281s4430/tak-dihapus-kemenag-revisi-materikhilafah-dan-jihad

Jalaludin Rahmat, Psikologi Komunikasi, (Bandung: Remaja Rosdakarya. 2013)

Abizar. 1988. Kemiskinan Organisasi. Dirjen Dikti Depdikbud. Jakarta

Bimo Walgito, Pengantar Psikologi Umum, (Yogyakarta : CV Andi Offset, 2013)

S Nasution, Teknologi Pendidikan, Bandung: CV Jammars, 1999, 
Anas Sudijono, Pengantar Evaluasi Pendidikan, Jakarta: Rajawali Pers, 2011,

Ngalim Purwanto, Prinsip-Prinsip dan Teknik Evaluasi Pengajaran, Bandung: Remaja Rosda Karya, 2010

Sardiman, Loc.Cit.

W.S. Winkel, Psikologi Pengajaran, Yogyakarta: Media Abadi, 2009

Asep Burhanudin, Jihad Tanpa Kekerasan, Yogjakarta, PT LkiS Pelangi Aksara, 2005,

Abdul Baqi Ramadhun, Jihad Jalan Kami, Terj., Imam Fajarudin. (Solo: Era Intrmedia, 2002),

Majid Khaduri, Perang dan Damai dalam hukum Islam, terj.Kuswanto, Yogyakarta, Tarawang Press, 2002,

Alaiddin Koto, Ilmu Fiqih dan Ushul fiqih, (Jakarta: PT Raja Grafindo persada, 2004)

Suharsimi Arikunto, Prosedur Penelitian Suatu Pendekatan Praktik, Edisi Revisi(Jakarta: Rineka Cipta, 2010),

Sugiyono,Statistika untuk Penelitian,(Bandung: Alfabeta, 2010),

Indonesia, Kementerian Agama, buku siswa fikih kelas xii, Jakarta 2016

Yazdi, M. Taqi Misbah, perlukah jihad? meluruskan salah paham seputar jihad, al huda, Jakarta 2016 